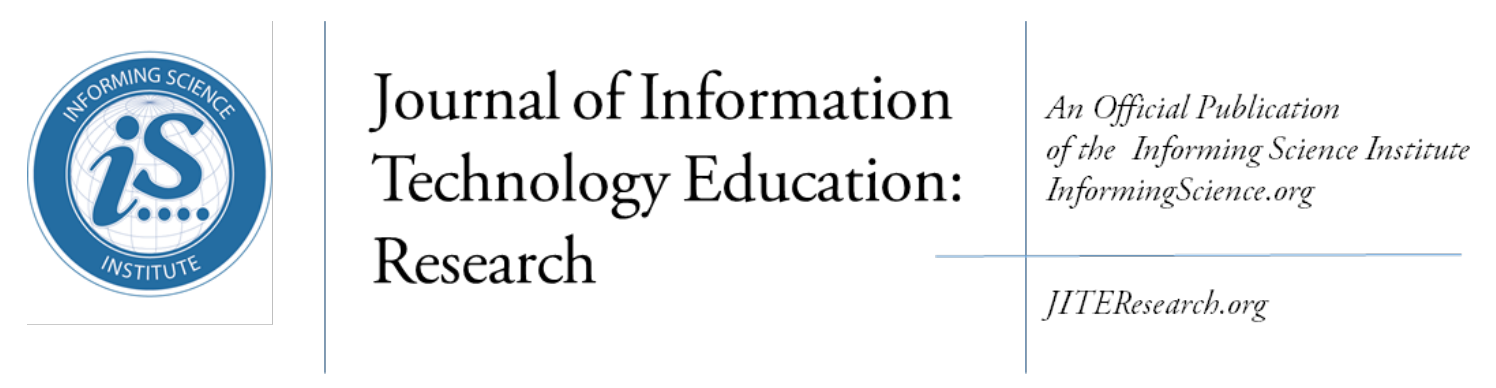

Volume 16, 2017

\title{
ARE Boys AND Girls STILl Digitally DIFFERENTIATED? 'THE CASE OF CATALONIAN TEENAGERS
}

\begin{tabular}{lll}
\hline Roser Cussó-Calabuig* & $\begin{array}{l}\text { University of Lleida (UdL), Lleida, } \\
\text { Spain }\end{array}$ & rcusso@xtec.cat \\
Xavier Carrera Farran & University of Lleida (UdL), Lleida, & carrera@pip.udl.cat \\
& Spain \\
Xavier Bosch-Capblanch & $\begin{array}{l}\text { Swiss Tropical and Public Health } \\
\text { Institute, Basel, Switzerland } \\
\text { and Universität Basel, Basel, } \\
\text { Switzerland }\end{array}$ \\
&
\end{tabular}

\begin{abstract}
Aim/Purpose This article presents a study of ICT use and attitudes related to the computer use of girls and boys from Catalonia in order to detect which gender differences may explain the low presence of women in the ICT field and to design a proposal of actions in schools to help reduce these differences.

Background Since the number of women in the field of ICT remains very low, this study looks into the factors that influence girls' lack of interest in ICT field.

Methodology The study collected data from 29 randomly selected public secondary schools in Catalonia with a total of 1,920 students ( 972 boys and 815 girls aged between 11 and 13 years old); it analyzes socio-demographic data, frequency and type of computers use and attitudes and self-efficacy on ICT use.

Contribution The study concludes there is a prevalence of stereotypes about the differences of skills and professional vocation among the teenagers and a gender difference when we focus on attitudes toward computers or self-efficacy.

Findings Boys and girls face computer use in different ways and both have a stereotyped image of their mothers' and fathers' digital skills and ICT jobs. Girls present higher levels of anxiety than boys when using a computer and lower selfconfidence. Boys have higher self-efficacy than girls when asked for their perception about doing tasks with computers.
\end{abstract}

Accepted by Editor Minh Huynh | Received: March 14, 2017| Revised: July 13, September 6, October 11, 2017 | Accepted: October 24, 2017.

Cite as: Cussó-Calabuig, R., Carrera Farran, X., \& Bosch-Capblanch, X. (2017). Are boys and girls still digitally differentiated? The case of Catalonian teenagers. Journal of Information Technology Education: Research, 16, 411-435. https://doi.org/10.28945/3879

(CC BY-NC 4.0) This article is licensed it to you under a Creative Commons Attribution-NonCommercial 4.0 International License. When you copy and redistribute this paper in full or in part, you need to provide proper attribution to it to ensure that others can later locate this work (and to ensure that others do not accuse you of plagiarism). You may (and we encourage you to) adapt, remix, transform, and build upon the material for any non-commercial purposes. This license does not permit you to use this material for commercial purposes. 
Are Boys and Girls still Digitally Differentiated?

Impact on Society Policy makers must design strategies to minimize these gender differences in order to engage more girls in technological studies and minimize this imbalance.

Future Research Future research is needed, in the Catalan context, about whether the intensive use of computers in schools can influence the reduction of the gender-gap and identify which interventions must be made to maximize its effect.

Keywords gender differences, attitudes in computer use, self-efficacy, secondary students, stereotypes in ICT

\section{INTRODUCTION}

Nowadays, boys and girls are frequent users of Information and Communication Technologies (ICT). According to the European Union Statistical Office (Eurostat, n.d., year searched 2015), 83\% of EU households have Internet access, $82 \%$ have at least one computer, $84 \%$ of the youth between 16 and 24 years old commonly use smartphones to access the Internet, and $80 \%$ of them use the computer on a daily basis. Access to technology is, hence, common and easy.

However, there are substantial gender differences in the use of ICT. Reports from the International Computer and Information Literacy Study (ICILS) (Fraillon, Ainley, Schulz, Friedman, \& Gebhardt, 2014) and the Organisation for Economic Co-operation and Development (OECD, 2015b), based on the Programme for International Student Assessment (PISA) tests, suggest that while girls have a more intensive use of ICT for communication, social networks included, than boys. Boys more often use ICT for leisure and gaming.

These differences in the use of ICT suggest a different approach to technology between boys and girls. While boys are focused more directly on programming and the technical aspects of computers, girls tend to focus on the end-use of software and applications, as has been shown in the report by the OECD (2015a) about gender and education.

Gender differences related to ICT can also be analyzed from other perspectives, for example, from the perception of gender stereotypes regarding the very nature of ICT, identified as a male field.

Another perspective, related to gender differences in relation to ICT, focuses on the attitudes expressed in its use and on the self-efficacy perceived by boys and girls. Girls show more anxiety than boys, as well as less confidence in their potential, and show less enjoyment carrying out tasks beyond those of a basic user.

These gender differences in the use of ICT, stereotypes, lack of models, attitudes, and self-efficacy may lead to differences in what they expect from technologies and how they approach them in their future. The fact is that there is a significant difference between the number of girls and boys enrolled in ICT careers. According to the Organisation for Economic Co-operation and Development (OECD, 2015a), the average percentage of women holding a Bachelor qualification or equivalent in the field of ICT (International Standard Classification of Education, ISCED2011 level 6) across all OECD member countries is $19.1 \%$. In Catalonia, where this study was carried out, women represented only $14.77 \%$ of all ICT graduates in 2016 .

This article investigates gender differences related to ICT in a sample of randomly selected secondary students from public schools in Catalonia. Our objective is to assess whether gender differences persist or not despite the increasing use of computers in schools in order to provide robust evidence to inform educational policies supporting the intensive use of computers in classrooms, taking into account gender issues.

Similar studies carried out in the Catalan context mainly focused on final-year secondary school students and had serious methodological limitations, such as using purposive rather than random samples, which can seriously bias findings (Everis, 2012; Sáinz, Meneses, Fàbregues, \& López, 2016). Our study is based on randomly selected students who had just begun the secondary school stage and can 
therefore provide findings of gender differences in early ages, precisely when there is a larger decision space for future professional orientations. The results show that these gender differences exist and that in some cases, as in the stereotypical vision of ICT professions or in the lack of confidence of girls in their own abilities, are remarkable.

The results of this study could inform the development of strategies to implement ICT along all secondary levels in order to reduce gender differences, allowing girls and boys (i) to achieve similar digital skills, (ii) to have the same possibilities of choosing their professional future, and (iii) to reverse the disproportionate low number of girls studying in this field.

\section{LITERATURE REVIEW OF FACTORS DETERMINING GENDER DIFFERENCES}

The gender gap in choosing ICT careers actually starts at very young ages, as suggested by Sjøberg and Schreiner (2010) in the ROSE Project (Relevance of Science Education). The ROSE project was based on a survey of 40,000 fifteen years old students from 40 countries carried out between the years 2003 and 2006. To the question asking students about their intention to develop their professional future in the field of ICT, around $50 \%$ of European boys responded that they were interested in jobs related to technology, but only $20 \%$ of girls did so. It is necessary to establish the reasons that lead to the difference in the decisions of boys and girls to eliminate the barriers that prevent them from making a free choice based only on their professional preferences.

\section{INFLUENCE OF FAMILY AND TEACHERS}

There is a wealth of research evidence on factors associated with the lack of girls' attraction to studying ICT and girls' low value given to a professional career in this field. Some studies (Sáinz \& LópezSáez, 2010; Sáinz, Pálmen, \& García-Cuesta, 2012; Stockdale \& Keane, 2016) suggest the relationship within the family and teachers as key factors.

Sainz et al. (2012) examine parents' and teachers' opinions about male and female career and occupational aspirations using focus groups in five secondary Spanish schools. They conclude that parents (particularly mothers) tend to view ICT professionals in a generally negative manner, as individualistic people, lacking social skills. The authors suggest that it is hard to believe that those parents would encourage their daughters to pursue an ICT career. In the same way, teachers tend to understand ICT as a typically male field. This means that the attention given to boys and girls in the classroom is likely biased and that any career advice given to students would also be stereotyped.

In order to address these perceptions, Stockdale and Keane (2016) carried out a pilot study targeting mothers of school children in Australia in order to change their views about ICT as being a nonfemale field. Mothers attended a training course to be introduced to basic ICT tools and learnt about the scope of ICT careers in order to be made aware of future possibilities for their children, especially girls. After the course, their views were recorded using a questionnaire and informal interviews.

The authors conclude that there was a change in the gendered misconception of ICT careers, suggesting that this could be an effective intervention, at least in the short run.

\section{STEREOTYPES AND ROLE MODELS}

Another known factor that influences gender differences are stereotypes of girls in relation to ICT studies and jobs and their lack of knowledge about the particularities of the jobs in this sector (Castaño \& Webster, 2011; Clayton, von Hellens, \& Nielsen, 2009; Master, Cheryan, \& Meltzoff, 2016; Pechtelidis, Kosma, \& Chronaki, 2015; Thomas \& Allen, 2006; von Hellens, Clayton, Beekhuyzen, \& Nielsen, 2009).

It is important to point out that these stereotypes are fully embedded in social perceptions about the male nature of ICT related jobs (Clegg, 2001). Accordingly, Cheryan, Plaut, Handron, and Hudson 
Are Boys and Girls still Digitally Differentiated?

(2013) expose in their paper how media give an image of masculinity in this field, which reinforces the girls' perceptions.

Thomas and Allen (2006) carried out exploratory research on boys' and girls' perceptions about ICT careers. The survey concluded that girls are far more negative about stereotypes in ICT jobs than boys. They consider people working in ICT as "geeks", asocial, primarily men who do a very technical job far from the real social needs. These misconceptions about the real attributions of technological jobs seem to prevent girls from getting involved in ICT careers.

Master et al. (2016) show in their paper how stereotypical environments can influence boys' and girls' choice. They suggest that girls in a non-stereotypical classroom are more interested in taking computer science courses than those who are in a stereotypical classroom. They conclude that redesigning the classroom can project a different image about ICT that can encourage girls to enrol in this area by making them feel like belonging to this environment.

The absence of female role models in the ICT field (Carrington, Tymms \& Merrell, 2008; Clayton, 2007) reinforces the perceptions of girls that ICT jobs are male dominated.

\section{ATTITUDES AND SELF-EFFICACY}

Another study area focuses on boys' and girls' attitudes about the use of ICT and their selfperceptions about their skills, problem solving strategies, learning, and the usefulness of digital tools. Gender differences in self-efficacy and attitudes may influence the ways boys and girls face ICT or how they conceive their academic and vocational projection (Colley \& Comber, 2003; Kubiatko, 2013; Volman, van Eck, Heemskerk \& Kuiper, 2005).

Girls' attitudes in the use of ICT are slightly lower than boys' (Adebowale, Adediwura \& Bada, 2009; Busch 1995; Chen, 1986; Ogan, Herring \& Robinson, 2005; Shashaani, 1993; Volman \& Van Eck, 2001). The term attitude has, however, different dimensions: anxiety, enjoyment, and self-confidence.

Anxiety is defined as fear to interact with ICT and showing overall negative attitudes towards ICT, which leads to a deterioration of tasks and their accomplishment (Shashaani, 1993).

In relation to anxiety, there is a disparity of findings among different authors. Some of them (Teo, 2008) found no differences between boys and girls, while others (Adebowale et al., 2009; Baloğlu \& Çevik, 2008; Kaino 2008; Kubiatko, Haláková, Nagyová, \& Nagy, 2011) report higher anxiety in girls as compared with boys.

Enjoyment is defined as interest in the use of ICT, not only in the academic context within or outside the school, but also during leisure time (Shashaani, 1993). The level of enjoyment has been widely reported as being similar for boys and girls (Adebowale et al., 2009; Fančovičová \& Prokop, 2008; Kaino, 2008; Ogan et al., 2005; Teo, 2008). However, some authors point at higher levels of enjoyment in boys than in girls (Fraillon et al., 2014). On the other hand, Kubiatko et al. (2011) found that enjoyment in the use of computers among girls was higher than among boys and that mean values of enjoyment decreased with age in girls and increased in boys. A factor that could explain these differences between studies may be the differences in ages in the samples of subjects included and differences in the use of computers in schools and at home.

Self- confidence is defined as the personal perception of controlling ICT tools, feeling comfortable when using them and feeling able to overcome difficulties by one's own means (Shashaani, 1993).

Self-confidence is consistently lower in girls (Christoph, Goldhammer, Zylka, \& Hartig, 2015; Ogan et al., 2005; Volman \& Van Eck, 2001). Boys tend to perceive themselves as "experts" in ICT, even when their objective knowledge is low, while girls seem to perceive themselves as less skilful and with less knowledge even if their objective knowledge shows no difference from boys' (Volman \& Van Eck, 2001). 
It is worth noting that computer use, which tends to be a rather informal and basic use, is predominant at home. However, self-confidence is assessed against tasks which are more specific and which require a relatively advanced computing level. In summary, the low self-confidence in girls seems to be associated with girls' tendency to undervalue themselves, boosted by informal self-learning (Volman \& Van Eck, 2001).

Self-efficacy is the conviction of one's own ability to successfully carry out a given task (Busch, 1995). Psychological studies relate self-efficacy to the likelihood of selecting or being interested in a task, the level of effort and the persistence in completing tasks (Bandura, 1978; Bandura \& Schunk, 1981). Bandura (1978) suggests several factors affecting self-efficacy perceptions; e.g. the experience of being successful in carrying out a task increases the self-efficacy related to that task; observing someone else's success or failure influences self-efficacy; verbal persuasion may have an impact on the possibilities of success; and the issue of one's emotional status. Self-efficacy is lower among girls (Durndell \& Haag, 2002; Miura, 1987). Downes and Looker (2011) established a correlation between self-efficacy and the intention of students to enrol in ICT studies in the future. Findings suggested that students with a high level of self-perceived computer ability were more likely to consider pursuing an ICT career. Again, some evidence suggests other factors such as frequent use of computers, parental support and teachers' roles may increase self-efficacy (Downes \& Looker, 2011; Papastergiou, 2008; Vekiri, 2010).

\section{RESEARCH CONTEXT}

Our research has developed from the current knowledge on the factors influencing gender differences in the use of ICT, as indicated in the Literature Review section, in the context of public secondary schools of Catalonia. This section discusses the research questions, the research context in the area of Catalonia, and the structure of the proposed questionnaire.

\section{RESEARCH QUESTIONS}

The research questions we address are:

- What is the socio-demographic context of boys' and girls' in relation to the use of computers in Catalonia and how does this influence their perception of ICT?

- How do boys and girls in Catalonia differ in relation to their habits in the use of computers?

- What are the gender differences between boys and girls in relation to their attitudes and perceived self-efficacy facing their work with computers?

\section{CONTEXT OF THE RESEARCH}

Catalonia is a region in Spain with a population of about 7 million. Most of the population lives in the capital cities of the four main sub-regions. Barcelona, Catalonia's capital, is the largest urban centre, with more than a quarter of the population.

Education services were devolved to the Catalonia's government in the late 70s and since then the Catalan government, remaining in Spanish state the more generic constitutional issues, has increasingly dictated education policies.

Educational centres are quite uniformly distributed across the whole Catalonian territory, including the most remote rural areas in the Pyrenees. Schools are bound to Catalonian law, including budgeting, although they have some degree of self-direction in the areas of management.

ICT content are included in Technology, a compulsory subject that has been taught in secondary schools in Catalonia since 1996. In primary education, there is not a formal Technology or ICT subject and computers are used or not by students depending on the pedagogical trends of each school. 
The number of girls studying ICT in Catalonia is very low and the trend in recent years has been maintained, with a slight increase in the last two years as shown in Figure 1.

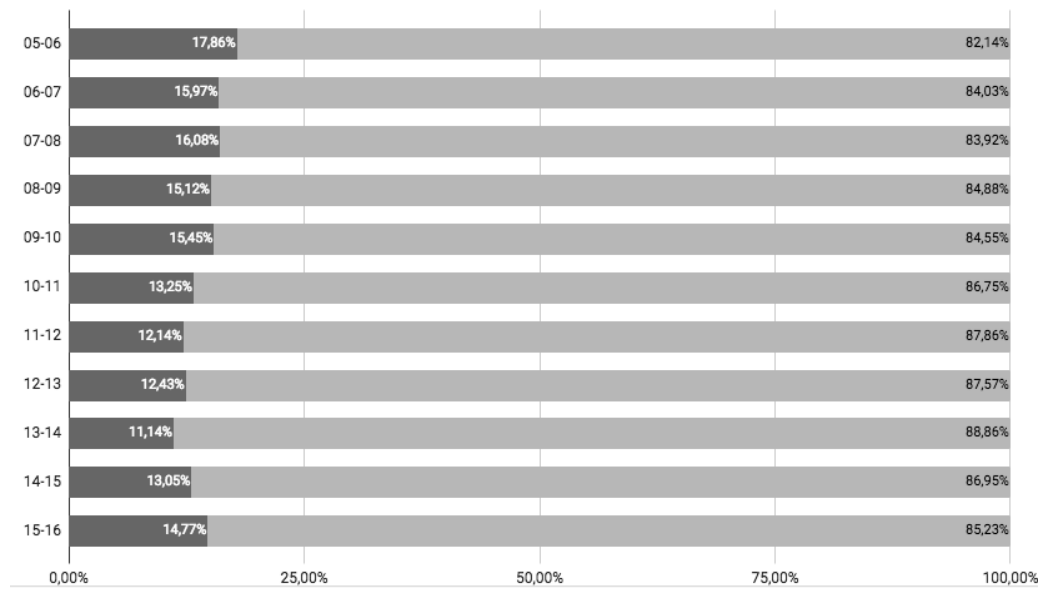

Figure 1. Percentage of females (in dark grey) and males (in light grey) graduated in ICT fields in Catalonia in the last ten years

In the research arena, some studies carried out in Catalonia have addressed this issue trying to find explanatory factors in undergraduate students (Everis, 2012; Sáinz et al., 2016). These studies suggest that stereotypes, attitudes, self-efficacy as well as family and teachers roles may influence gender differences in ICT career paths However, participants in these studies were secondary school boys and girls, at an age at which it is well known that key future career choices have already been made (Sjøberg \& Schreiner, 2010). On the other hand, these studies had a high risk of bias due to the use of purposive rather than random samples of individuals or mixing very different age ranges (e.g., 13 to 20 years old). Our research focuses on students in the first course of secondary school, between 11 and 14 years (mean 12.2 years), when career choices have not yet been made and just when students start the formal curriculum content of ICT. At these ages, we are able to capture their perceptions before students start ICT formal training and before they formally conceive their choices for their future jobs. Furthermore, by researching in an earlier age group, lessons learned from this research can still be considered when devising interventions in the secondary school period.

The data were collected through a questionnaire applied to secondary students of Catalan public schools. Its structure corresponds to the research questions, and the included variables were sociodemographical data, attitudes in the use of ICT (i.e., anxiety, enjoyment and self-confidence), and self-efficacy. See the Literature Review section for more details.

The socio-demographic section describes personal and contextual features of students, following similar approaches in previous studies (Busch, 1995; Chen, 1986; Durndell \& Haag, 2002; Ogan et al., 2005; Shashaani, 1993). Sáinz and López-Sáez (2010), and Stockdale and Keane (2016) indicate the importance of the influence of the family in the stereotypical perception of the ICT jobs and in the choice of studies and the professional orientation of the girls and boys. Accordingly, this section of the questionnaire aimed at capturing the perceptions of the boys and girls about family stereotypes regarding their parents' digital competencies.

The frequency of use of computers section includes a series of routine tasks carried out with computers outside schools. Tasks were drawn from the PISA 2003 (OECD, 2005) and PISA 2009 (OECD, 2012) questionnaires.

Attitudes in relation to computer use are classified into three domains (anxiety, self-confidence, and enjoyment), following the CAS scale (Computer Attitude Scale) defined by Loyd and Gressard (1984). 
As indicated by Colley and Comber (2003), Volman et al. (2005), and Kubiatko (2013), attitudes may influence the ways boys and girls face ICT and their professional projection in this field. High anxiety in girls, as reported by Baloğlu and Çevik (2008), Kaino (2008), Adebowale et al. (2009), and Kubiatko et al. (2011), and girls' low self-confidence, as reported by Volman and Van Eck (2001), Ogan et al. (2005), or Christoph et al. (2015), may contribute to a low achievement of digitals skills. On the other hand, enjoyment seems to be similar for both genders, according to Ogan et al. (2005), Fančovičová and Prokop (2008), Kaino (2008), Teo (2008), and Adebowale et al. (2009) but higher in girls than in boys at early ages (Kubiatko et al., 2011). We believe it is relevant to know whether this is also the situation of the Catalan students at the beginning of secondary education or not and to consider taking advantage of this enjoyment to develop more entertaining and effective ICT activities.

Self-efficacy is estimated based on (a) the tasks that someone wants to carry out while perceiving incapacity to complete them, and (b) the tasks that are perceived as being attainable. The details of the tasks proposed in this section of the questionnaire were drawn from the PISA 2003 (OECD, 2005) and PISA 2009 (OECD, 2012) questionnaires. As pointed out by Downes and Looker (2011), the level of self-efficacy is correlated with the intention of students to enrol in ICT careers. According to Durndell and Haag (2002), low levels of self-efficacy shown by girls may explain the low numbers of girls enrolling in ICT studies.

\section{MATERIAL AND METHODS}

Gender differences related to demographic context, frequency of use of computers, attitudes, and self-efficacy in relation to ICT have been typically measured in the literature using quantitative methods applied to indicators from validated questionnaires. Some examples of quantitative studies include Kubiatko (2013), Kaino (2008), Fraillon et al. (2014), Christoph et al. (2015) and OECD (2015a). In order to address the gap of evidence on gender differences in early ages in Catalonia and to allow a meaningful discussion with existing evidence worldwide, we decided to follow a quantitative approach, in which we carried out a quantitative, observational, cross-sectional, school-based study in a random sample of public schools in Catalonia. This approach allowed us to use validated questionnaires and to suggest comparisons with the findings of similar studies.

\section{SAMPLE}

The public Catalan education system consists of 537 secondary schools. In 2010, the Government of Catalonia defined a programme focused on an intensive use of computers in schools. This one-toone programme with students owning personal netbooks was not mandatory for schools.

The sample of selected schools was drawn from all 537 governmental secondary schools in Catalonia, some of them enrolled in the intensive use of computers programme. Because we knew that there could be differences in individuals attending schools with and without intensive use of computers, we used a stratified sampling technique to include a balance sample of individuals from both types of schools. Anticipating a low response rate, we included all 175 schools not following the intensive use of computers programmes; and then the same number of 175 schools randomly selected from the 362 schools following the intensive use of computers programme. No school was excluded on the grounds of geographical location, size, or any other reason. Figure 2 shows the distribution of participating schools. It is worth noting that points with a high-density of schools correspond to high-density population areas (see Figure 2). Schools were considered as clusters and all eligible students were selected in each school or cluster.

All selected schools were approached by an email addressed to the school headmaster. One reminder was sent to non-respondents two weeks after the first one.

We received 1920 responses, 972 for boys and 948 for girls from 29 schools; 13 (45\%) followed the intensive use of computers programme and $16(55 \%)$ did not. Students were 11 to 14 years old (mean 12.2 years). 


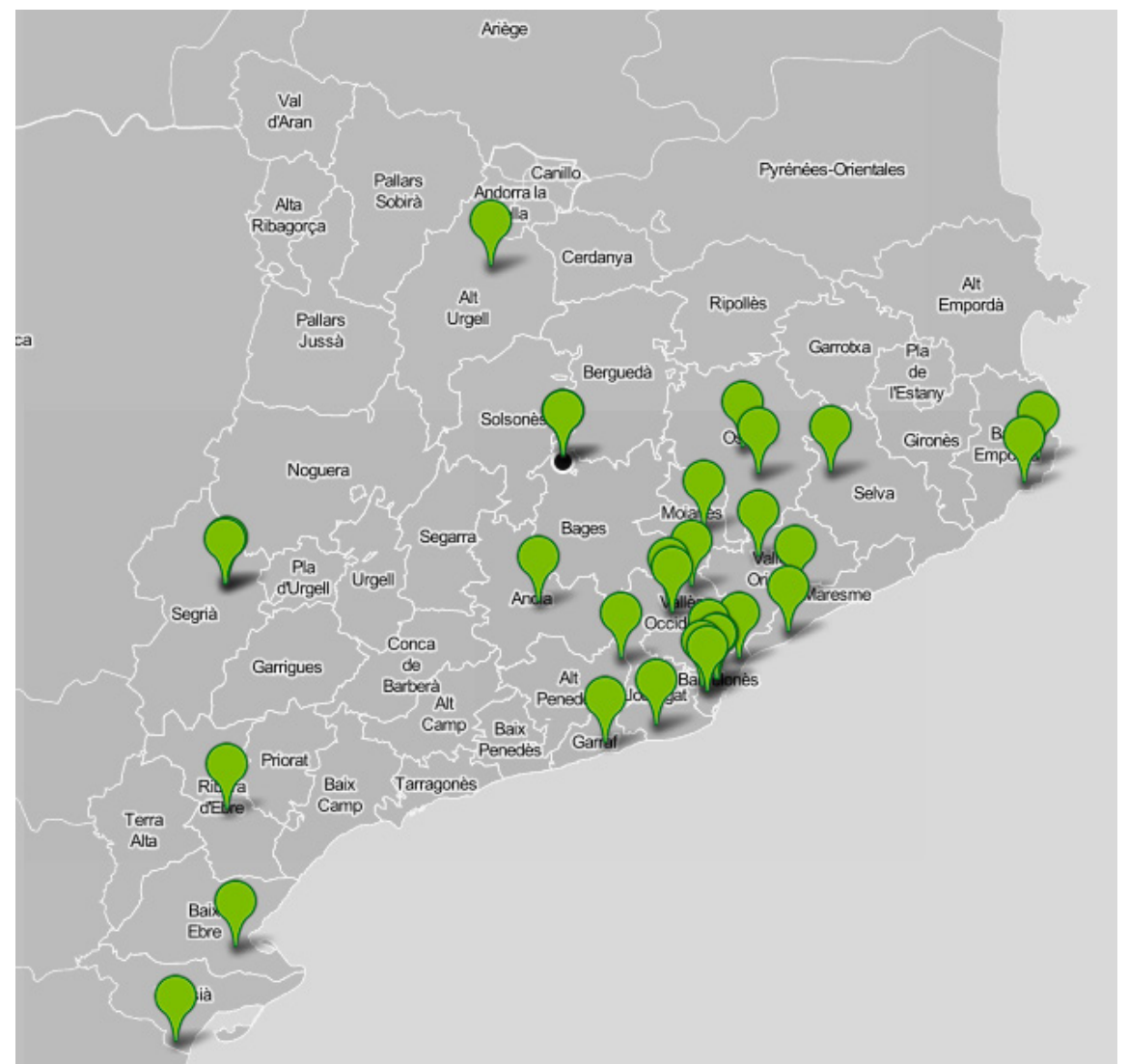

Figure 2. Distribution of schools

\section{QUESTIONNAIRE}

The questionnaire was structured into four sections, following the research questions: sociodemographic context, frequency of use, attitudes while using computers, and self-efficacy. Except for the first section, which is general and context-specific, the other sections were drawn from validated questionnaires and used a four-categories Likert scale (further described below). Where applicable, responses were codified and shown through a drop-down box to minimise entry errors. The questionnaire contained the following categories.

1. What is the boys' and girls' socio-demographic context in relation to the use of computers in Catalonia and how does this influence their perception of ICT?

This section includes information about (a) gender, (b) age, (c) school, (d) starting age in the use of computers, (e) place where computer use began, (f) reference place for computers use learning, (g) computing knowledge level of father and (h) mother, and (i) reference person to address computer problems.

2. How do boys and girls in Catalonia differ in relation to their habits in the use of computers?

The frequency of computer use section includes questions about a series of routine tasks carried out with computers outside schools: (a) on-line gaming, (b) social networks participation, (c) homework, (d) email use, (e) participation in chats, (f) Internet browsing, (g) downloads of media, and (h) management of personal web sites.

The statement in the questionnaire is, "Tell us how often you carry out the following tasks using a computer". Responses (in 4 levels Likert scale) ranged from "Never or hardly ever" (1 point), "Once or twice per month" (2 points), "Once or twice per week" (3 points) and "Almost daily" 
(4 points). This scale is based on that used in PISA questionnaires. We included "Once or twice a month" to allow responses for some specific actions that could be unusual (e.g., "Management of personal web sites").

3. What are the gender differences between boys and girls in relation to their attitudes and perceived self-efficacy facing their work with computers?

This research question is addressed in two separate sections in the questionnaire: attitudes and self-efficacy.

The section about attitudes in relation to computer use includes questions related to the three domains of anxiety, self-confidence and enjoyment, following the CAS scale (Computer Attitude Scale) defined by Loyd and Gressard (1984). The CAS scale has 30 items groups in three subscales corresponding to the three domains, although statements are mixed and not structured around domains.

We decided to use the CAS scale because it is one of the most used in similar studies (Blignaut, 2006; Francis, 1994; Powell, 2013; Selwyn, 1997) and because it has been widely validated (Gardner, Discenza, \& Dukes, 1993; Garland \& Noyes, 2008; Nash \& Moroz, 1997; Powell, 2013). Yet, we adapted some question statements, which were out of use, to the context of this study. The scale was translated into Catalan, which is the vehicular language in the schools of Catalonia.

The introductory explanation to the questions in this section is "Indicate the extent to which you agree or disagree with the ideas expressed". Five questions in each domain are formulated in a negative sense to minimize automatic answering and to stimulate a careful reading of the questions. Responses (4 Likert levels) ranged from "Strongly disagree" (1 point), "Disagree" (2 points), "Agree" (3 points) and "Strongly agree" (4 points). Although the former CAS scale ranges from 1 to 5 , we have adopted ranges from 1 to 4 after findings from recent studies suggesting that these scores are more appropriate to prevent students from overusing the neutral middle score (Farkas \& Murthy, 2005; Varank, 2007)

Self-efficacy is addressed asking the perceived capacity to complete specified tasks using computers classified into basic and advanced. The first tasks include (a) digital edition of pictures, (b) production of a presentation, in general, (c) creation of a text document, (d) working with collaborative documents, and (e) reading and responding to emails; the latter include (f) database creation, $(\mathrm{g})$ use of spread sheets, $(\mathrm{g})$ production of a presentation with images and sound, $(\mathrm{h})$ designing a web site, and (i) creating a blog.

The question statement is: "Tell us what you think your level of expertise is in the following tasks". The scale (4 levels Likert) ranged from "I don't know what it means" (1 point) to, "I can't do it" ( 2 points), "I can do it with help" (3 points) and "I can do it on my own" (4 points).

Internal consistencies of the questionnaires (Cronbach's $\alpha$ ) were $0.80,0.85$ and 0.8 , for the three domains frequency of use of computers, attitudes and self-efficacy, respectively. All the questions can be found in Appendix A.

\section{PROCEDURE}

The questionnaire was on-line using Google Form platform (see Figure 3) and self-administered (https://goo.gl/forms/h5yeMezoyc45fUJw2)

Once the questionnaire was completed and translated it was piloted to ensure the coherence of the structure and the understanding of the specific terms of the CAS scale. The questionnaire was administered to 50 first-year, secondary school students in a school, resulting in the rephrasing of two questions in the section of attitudes. Other aspects, such as data consistency and completeness using the Google Form platform, were also verified. It was estimated that it would take around 20 minutes to fill in the questionnaire. 
Are Boys and Girls still Digitally Differentiated?

The extensive application was undergone during the first term of the academic year, when the ICT programmes were introduced and hardly any impact on attitudes and self-efficacy could be expected. The questionnaire was accompanied by instructions for the teachers who would support students in responding to the questionnaire in the classrooms.

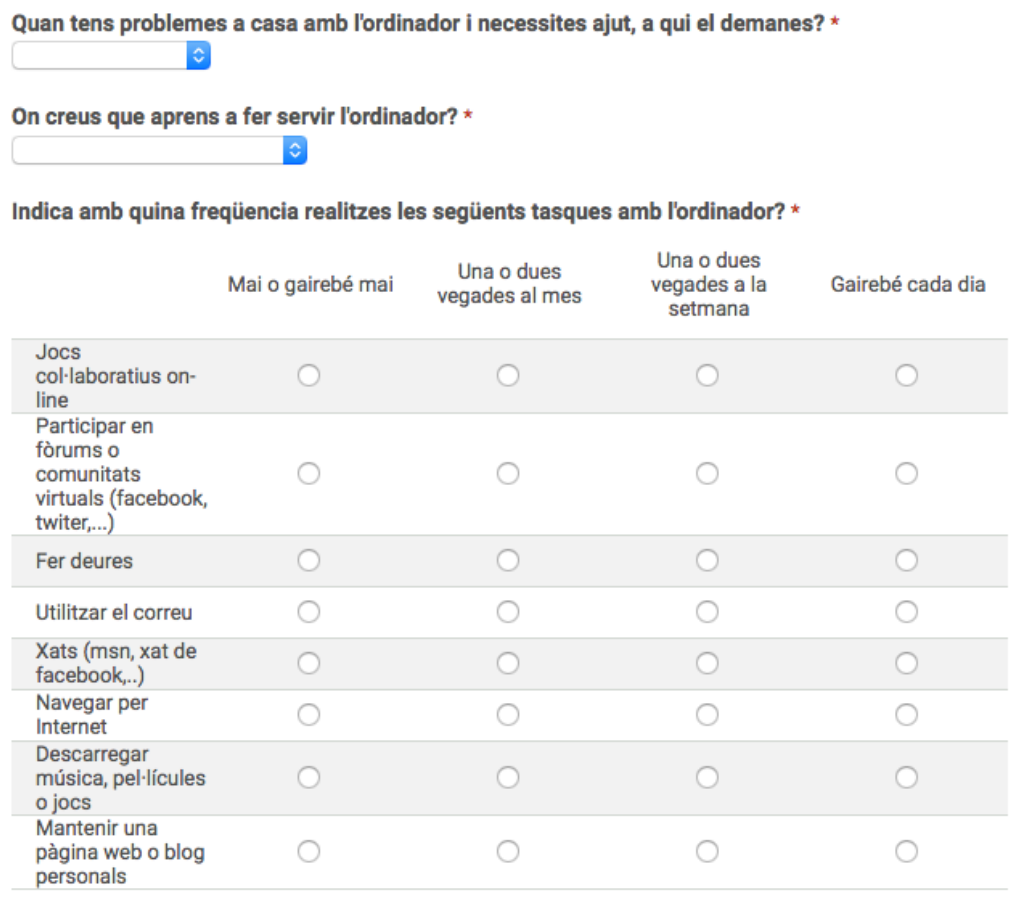

Figure 3. Screen-shot of the on-line questionnaire

\section{DATA ANALYSIS}

All variables were analysed individually. Furthermore, certain variables were combined to build the indicators defined in the questionnaires (PISA 2003, PISA 2009, CAS), as follows.

Variables related to frequency of use were grouped in four categories: leisure (i.e., on-line gaming, Internet browsing, downloading of media, management of personal Web sites), homework, communication (i.e., participation in social networks, use of email, participation in chats), and games. The latter was analysed individually despite being included in 'leisure' given the gender differences reported in several studies.

Negative statements in the attitudes domain were recoded to maintain consistency with the rest of the statements. The overall attitude score was estimated adding the values of each question and subscale. All questions had the same weight.

Self-efficacy questions were grouped according to the two categories: basic (i.e., digital edition of pictures, production of a presentation, creation of a text document, working with collaborative documents and reading and responding to emails) and advanced (i.e., database creation, use of spread sheets, production of a presentation with images and sound, designing a web site and creating a blog). The overall score was obtained averaging the scores across questions.

Descriptive statistics included percentages, means and their 95\% confidence intervals, estimated by taking into account the clustering design of the sample. Results are presented disaggregated by gender. All statistics were carried out using Stata 13.0. 


\section{RESULTS}

The results are shown for each of the four sections of the questionnaire related to the research questions as exposed in the Material and Methods section of this paper.

\section{SOCIO-DEMOGRAPHIC CONTEXT}

\section{Factors related to the start in the use of computers and learning of their use}

Boys have an earlier start in the use of computers than girls: $37.9 \%$ of boys report having used computers when they were younger than six years old, as compared with $34 \%$ of girls. From nine years of age, there is hardly any difference (see grey areas in Table 1).

Both boys and girls report that they started using computer mainly at home (grey area in Table 1). The school was the second most often reported place of initiation, in a remarkable lesser proportion of cases.

When asked about where boys and girls learned to use computers, the answers suggested no differences between genders; both reported learning at home (see grey area in Table 1), typically without any help in very similar proportions. The school was the second most often reported place of learning. Details on these answers can be found in Table 1.

\section{Table 1. Results of social-demographic context}

(Grey areas indicate the higher values for each variable; note that for "Age of initiation" there are two grey areas, due to similar values in two responses)

\begin{tabular}{|lcccc|}
\hline & \multicolumn{2}{c}{ BOYS } & \multicolumn{2}{c|}{ GIRLS } \\
\cline { 2 - 5 } AGE OF INITIATION & Percentage & SE & Percentage & SE \\
Before 6 & & & $34.00 \%$ & 1.98 \\
Between 6 and 8 & $37.91 \%$ & 2.24 & $46.90 \%$ & 1.57 \\
Between 9 and 11 & $42.42 \%$ & 1.48 & $17.94 \%$ & 1.66 \\
12 and more & $18.44 \%$ & 1.76 & $1.15 \%$ & 0.50 \\
PLACE OF INITIATION & $1.23 \%$ & 0.32 & & \\
At home & & & $70.20 \%$ & 1.69 \\
At school & $71.00 \%$ & 1.51 & $20.04 \%$ & 1.72 \\
Relative's home & $18.14 \%$ & 1.67 & $4.41 \%$ & 0.72 \\
Friend's home & $5.23 \%$ & 0.78 & $1.78 \%$ & 0.43 \\
Others & $2.66 \%$ & 0.62 & $3.57 \%$ & 0.75 \\
PLACE OF LEARNING & $2.97 \%$ & 0.68 & & \\
Alone at home & & & & \\
At school & $51.33 \%$ & 2.39 & $52.78 \%$ & 2.18 \\
At home with help & $26.64 \%$ & 2.16 & $24.55 \%$ & 2.17 \\
With friends & $15.78 \%$ & 1.51 & $16.89 \%$ & 1.54 \\
\end{tabular}

\section{Skills in fathers' and mothers' use of ICT}

Both boys and girls feel that the level of their fathers' computer knowledge is higher than that of their mothers. Taking into account the responses "Very high" and "High", 58.6\% of boys and 63.3\% of girls report that their fathers' computer knowledge is very high or high; and $44 \%$ of boys and $47.2 \%$ of girls reported that their mothers' computer knowledge is very high or high (see grey areas in Table 2).

As shown in Table 2, these findings are consistent with students' responses in relation to the resolution of computer challenges. Both girls and boys reported that their reference resource to address computer challenges are fathers (see grey area in Table 2), followed by their siblings and finally by their mothers. Girls reported mothers as reference person relatively more often than boys. Boys more often than by girls reported friends as reference person. 
Are Boys and Girls still Digitally Differentiated?

Table 2. Results of perception about fathers' and mothers' computer skills

(Grey areas indicate the high levels for mothers' and fathers' computer skills

and the higher value for the variable References)

\begin{tabular}{|lcccc|}
\hline & \multicolumn{2}{c}{ BOYS } & \multicolumn{2}{c|}{ GIRLS } \\
\cline { 2 - 5 } FATHER'S LEVEL & Percentage & SE & Percentage & SE \\
Very high & & & & \\
High & $22.54 \%$ & 1.45 & $23.82 \%$ & 1.89 \\
Low & $36.07 \%$ & 1.69 & $39.56 \%$ & 1.56 \\
None & $26.64 \%$ & 2.01 & $23.09 \%$ & 1.59 \\
No response & $7.68 \%$ & 1.07 & $7.35 \%$ & 1.01 \\
MOTHER'S LEVEL & $7.07 \%$ & 0.96 & $6.19 \%$ & 1.04 \\
Very high & & & & \\
High & $12.70 \%$ & 1.28 & $12.59 \%$ & 1.16 \\
Low & $31.35 \%$ & 1.61 & $34.73 \%$ & 1.54 \\
None & $40.37 \%$ & 1.70 & $42.71 \%$ & 1.65 \\
No response & $10.45 \%$ & 1.40 & $6.61 \%$ & 0.97 \\
REFERENCES & $5.12 \%$ & 1.03 & $3.36 \%$ & 0.65 \\
Father & & & & \\
Mother & $42.01 \%$ & 2.39 & $41.34 \%$ & 2.11 \\
Brother/Sister & $16.91 \%$ & 1.39 & $20.25 \%$ & 1.31 \\
Friends & $30.33 \%$ & 2.23 & $30.43 \%$ & 2.01 \\
& $10.76 \%$ & 1.21 & $7.97 \%$ & 0.85 \\
\hline
\end{tabular}

\section{FREQUENCY AND HABITS IN THE USE OF ICT}

Data related to frequency and habits in the use of ICT, attitudes towards the use of ICT, and selfefficacy in the use of computers can be seen in Figure 4. Variables with non-overlapping 95\% confidence intervals are highlighted, suggesting significant differences between genders. We have numbered the key variables in the text and in Figure 4 to ease the narrative of the findings.

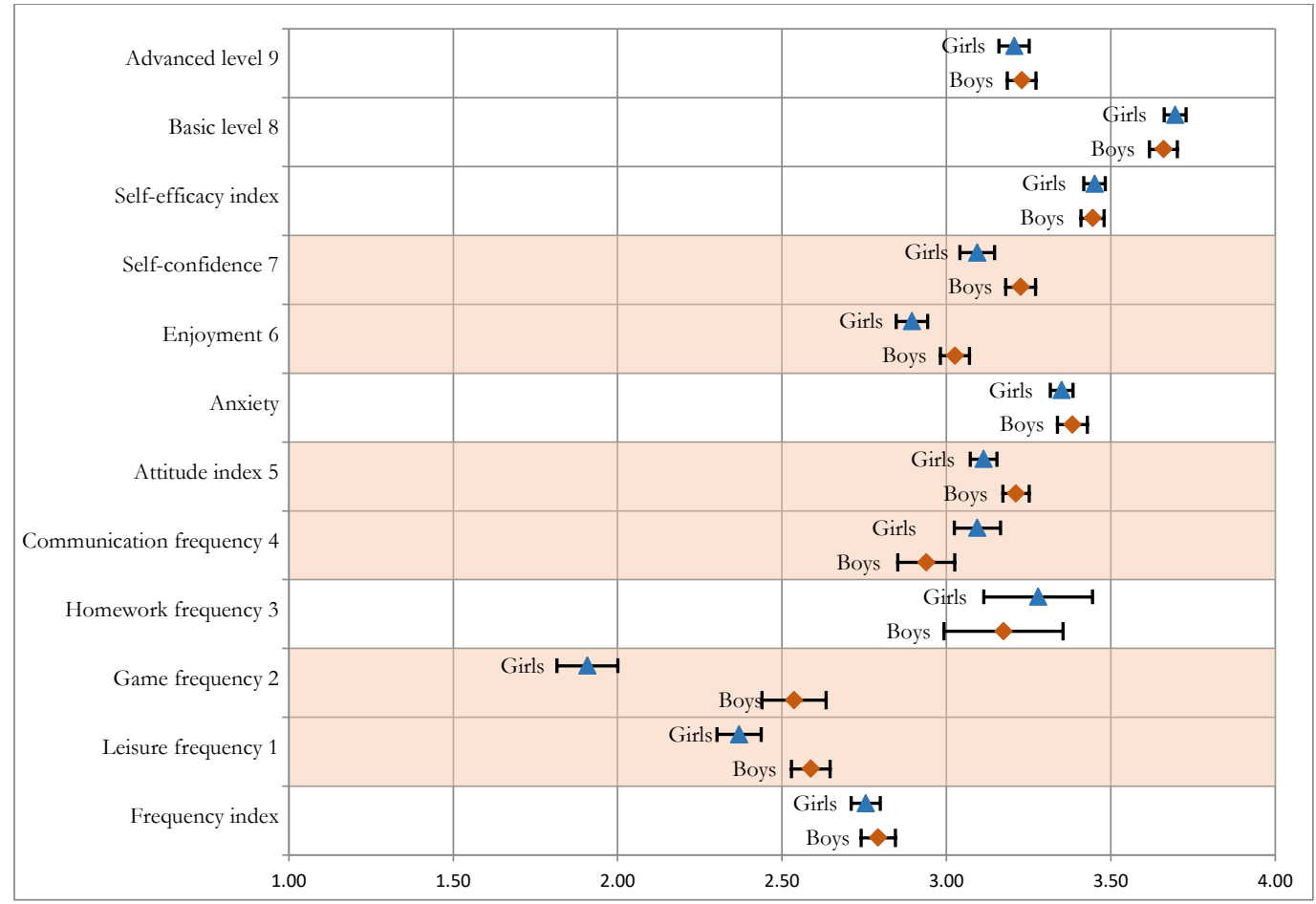

Figure 4. Results of Frequency of use, Attitudes and Self-efficacy

(Numbers corresponds to explanation in text and to relevant results;

Coloured areas means variables with 95\% confidence interval not overlapping) 
There were no differences between boys and girls in the computers' frequency use index, both reporting using computers more than once or twice a month (means: boys $=2.79, \mathrm{SE}=0.025$; girls $=$ $2.75, \mathrm{SE}=0.021)$. Differences became apparent when looking at the specific habits in the use of computers and their frequency of use (i.e., leisure, gaming, homework and communication, see the Questionnaire section).

In relation to leisure, there were slight gender differences: the frequency in the use of computers by girls was below boys and also in the lower range of use (means: boys $=2.59, \mathrm{SE}=0.028$; girls $=2.34$, $\mathrm{SE}=0.033$ ), with non-overlapping 95\% confidence intervals, as seen in Figure 4 (number 1 and coloured area).

These gender differences were larger in the computers' frequency of use for gaming. Girls reported lower frequency of use below the mid point in the score scale (mean $=1.91, \mathrm{SE}=0.045)$; and boys a frequency slightly above the middle point $($ mean $=2.54, \mathrm{SE}=0.048)$. These gender differences are the largest of all features studied, without overlapping confidence intervals (see Figure 4, number 2 and coloured area).

The use of computers for homework was very similar in boys and girls, the latter being marginally higher in girls (means: boys $=3.17, \mathrm{SE}=0.088$; girls $=3.28, \mathrm{SE}=0.080$ ). Confidence intervals are substantially larger than those measured in the other parameters, which suggest larger variability between individuals of the same gender group (see Figure 4, number 3).

Differently from the patterns described above, the use of computers for communication was slightly higher in girls (mean $=3.09, \mathrm{SE}=0.034)$ than in boys (mean $=2.94, \mathrm{SE}=0.042)$ with hardly overlapping $95 \%$ confidence intervals (see Figure 4, number 4 and coloured area).

The full set of results can be found in Appendix B.

\section{ATTITUDES TOWARDS THE USE OF ICT}

Boys and girls showed some differences in their attitudes towards the use of computers measured with the 'Attitudes index'. We report separately the three dimensions of this feature: anxiety, enjoyment, and self-confidence. 95\% confidence intervals for the overall index did not overlap, suggesting that underlying differences in attitudes features may be significant (means: boys $=3.21, \mathrm{SE}=0.019$; girls $=3.11, \mathrm{SE}=0.019)$; see Figure 4, number 5 and coloured area).

Anxiety reported by girls was marginally higher than that reported by boys and it was very low in both groups (means: boys $=3.38, \mathrm{SE}=0.022$; girls $=3.35, \mathrm{SE}=0.017$ ), which is consistent with the early start and high intensity in the use of computers, as shown in previous sections. Higher values mean a lower anxiety level.

Enjoyment was somehow lower for girls. Boys showed high values (mean $=3.03, \mathrm{SE}=0.022)$ and girls' values close to the mid point in score scale (mean $=2.89, \mathrm{SE}=0.017$ ) (Figure 4, number 6 and coloured area). Self-confidence in girls was below boys' as well, yet above the mid point in both groups (means: boys $=3.22, \mathrm{SE}=0.022$; girls $=2.89, \mathrm{SE}=0.023$ ) (Figure 4, number 7 and coloured area). $95 \%$ confidence intervals did not overlap in any of these two dimensions as seen in Figure 4.

The full set of data can be found in Appendix B.

\section{SELF-EFFICACYIN THE USE OF COMPUTERS}

The self-efficacy index in both genders was very close and in the higher end of the score scale (means: boys $=3.44, \mathrm{SE}=0.017$; girls $=3.45, \mathrm{SE}=0.016$ ). We report on the two levels of selfefficacy: basic level and advanced level.

In relation to basic self-efficacy, there was hardly any difference between genders. Values were in the higher end of the scale in both groups (means: boys $=3.66, \mathrm{SE}=0.021$; girls $=3.69, \mathrm{SE}=0.016$ )

(Figure 4, number 8). 
Are Boys and Girls still Digitally Differentiated?

Similarly, in the advanced level self-efficacy score, both genders reported values in the higher end of the scale (means: boys $=3.23, \mathrm{SE}=0.021$; girls $=3.21, \mathrm{SE}=0.022$ ) (Figure 4, number 9).

$95 \%$ confidence intervals overlapped in these two dimensions, as seen in Figure 4, suggesting very slight differences between boys and girls. Interestingly, and as expected, overall advanced level of self-efficacy was overall lower than basic-level self-efficacy. Although boys and girls reported almost the same values in both dimensions, it is remarkable that girls score above boys in the basic level and that the situation was the opposite for the advanced level of self-efficacy.

The full set of data can be found in Appendix B.

\section{DISCUSSION}

\section{SOCIO-DEMOGRAPHIC CONTEXT}

Our findings relating to the start of computer use (more than $80 \%$ before 8 years old, both boys and girls; see Table 1) are consistent with those in the OECD (2015a) report on gender and education, based on the PISA 2012 findings. This report shows that the average age when students start using computer is 6.9 years, boys starting earlier than girls.

Both boys and girls responded that they started using computers at home, similar to the findings from the ICILS report (Fraillon et al., 2014) and from the OECD gender and education report (2015a).

Indeed, the availability of computers in most households can explain the relatively early initiation age and the fact that they start at home. This is well illustrated in the OECD (2015b) report on students and computers showing an increasing trend in the use of computers from the year 2009 to 2012. Indeed, only $4 \%$ of 15 year-old students in 2012 reported not having a computer at home in this report.

However, one question remains: to what extent are computers used in schools and, more importantly, how can this use impact on ICT perceptions in both genders, given that the use at household level is already very prominent? Taking into account that these are students starting secondary school, they could have reported on their computer use in primary education. The lack of relevance of past experience in schools with computers, compared with household use, was striking. This finding seems to suggest that, as currently designed, ICT approaches in schools do not really bring an added value to what students already experiment at home.

The 2015 annual statistical report from the Education Department of the Government of Catalonia on digital equipment and their use at schools (Generalitat of Catalonia, 2017) shows that in $67.7 \%$ of primary schools there are less than five students per computer. This is a relatively low proportion as compared with secondary schools. Furthermore, $79 \%$ of primary schools report that the use of computers is mainly of academic nature, which actually includes the use of computers for tasks, which do not really involve capacity building of computer skills by students. What this suggests is that students hardly value schools as the ICT primary learning sites for ICT. In other words, data on the availability of ICT equipment and on generic use of computers do not necessarily portray or correlate with activities focusing on real ICT learning. Our data confirms this observation and calls for the need to revise the indicators reported by the government on the use of computers in schools.

Both boys and girls suggest that their fathers' digital skills are stronger than those of their mothers, overall in seeking help to solve computer problems. We have compared these perceptions with the digital knowledge levels of men and women between 25 and 54 years in Spain (the age range which typically includes the parents of children in our sample), information that is available in the Eurostat's Digital Economy and Society database (European Union Statistical Office, n.d., year searched 2015). In relation to fathers, there is some consistency between students' perceptions and the Eurostat data. However, mothers are heavily undervalued, with fewer students giving high values to their 
mothers' skills and also more students giving low values to mothers (see Table 3). In other words, teenagers' perceptions do not seem to be rooted in differences in the real skills of their parents.

A possible explanation could be that fathers spend more time at home using computers than mothers. However, there is no evidence to support this statement; according to Eurostat's Digital Economy and Society database (European Union Statistical Office, year searched 2015), 72\% of men and $71 \%$ of women aged between 25 and 54 in Spain use computers at home, and $83 \%$ of men and $83 \%$ of women have used computers at home within the last three months.

If there are no real differences between fathers and mothers in their ICT skills and use of computers at home, it could be that teenagers have a gender stereotype which our data support, showing an undervaluation of mothers by both boys and girls.

Table 3. Informatics knowledge level (rates) by gender, for men and women between 26 and 54 years old in Spain (European Union Statistical Office, n.d., year searched 2015), compared with boys' and girls' perceptions about fathers' and mothers' knowledge.

\begin{tabular}{|c|c|c|c|c|c|c|c|}
\hline & & FATHER & & & & MOTHER & \\
\hline & $\begin{array}{l}\text { Measured in } \\
\text { adults }\end{array}$ & $\begin{array}{l}\text { Perceived by } \\
\text { boys }\end{array}$ & $\begin{array}{l}\text { Perceived by } \\
\text { girls }\end{array}$ & & $\begin{array}{l}\text { Measured in } \\
\text { adults }\end{array}$ & $\begin{array}{l}\text { Perceived by } \\
\text { boys }\end{array}$ & $\begin{array}{l}\text { Perceived by } \\
\text { girls }\end{array}$ \\
\hline Very high & 36 & 22.5 & 23.8 & Very high & 33 & 12.7 & 12.6 \\
\hline Low & 24 & 26.6 & 23.1 & Low & 28 & 40.4 & 42.7 \\
\hline None & 3 & 7.7 & 7.3 & None & 2 & 10.4 & 6.6 \\
\hline
\end{tabular}

\section{FREQUENCY AND HABITS IN THE USE OF ICT}

Our findings related to the frequency in the use of computers are consistent with data from other sources (Instituto Nacional de Estadística, n.d., year searched 2015; Institut d'Estadística de Catalunya, n.d., year searched 2015; European Union Statistical Office, n.d., year searched 2015), which suggest that $50 \%$ of girls and $62 \%$ of boys in the same age range as our sample use computers on a daily basis. This relatively high frequency in the use of computers may correlate with easiness in accessing computers, commonly in the households.

Girls use computers for leisure less often than boys, as shown in ICILS (Fraillon et al., 2014) and $\operatorname{OECD}(2015 \mathrm{a}, 2015 \mathrm{~b})$ reports. This is also the case of the use of computers for online gaming, being more prevalent in boys than in girls as shown in the OECD (2015a) report on gender and education. The same reports also suggest a similar level of use for school activities in both genders and a more intense use for communication activities by girls (e.g., social networking). These findings are consistent with our results suggesting that Catalonian girls and boys share the trends of the OECD countries.

Why are gender differences in gaming and communication the most remarkable ones? Likely gaming use may be influenced by aggressive computer games marketing, which clearly target boys in the design and underlying strategies of games (Kafai, Heeter, Denner, \& Sun, 2008). Girls tend to not identify themselves with games entailing fighting and strong competition, which are the most common in the market and which link computers with male stereotypes.

It is worth noting that the use of computers in gaming may lead to a greater interest in the technicalities of ICT, such as programming or hardware, and to a higher self-confidence in the use of computers. This can contribute to the differences between boys and girls in self-confidence, as shown in our results. Furthermore, it could contribute to the predominance of ICT studies as a professional career in boys as compared to girls, as self-confidence has been shown to be a predictor of choices of future studies (Abiss, 2011; Shashaani, 1993) 
Are Boys and Girls still Digitally Differentiated?

On the other hand, gender difference in the use of computers for communication may reflect girls' needs to establish links with their peers in the adolescent period. This would be consistent with the lack of engagement of girls in computer gaming, which is usually individualistic in nature.

\section{ATTITUDES IN THE USE OF ICT}

Overall girls' attitudes were slightly lower than boys', consistent with findings in other studies (Adebowale et al., 2009; Busch 1995; Chen, 1986; Ogan et al., 2005; Shashaani, 1993; Volman \& Van Eck, 2001). However, some of the attitude dimensions showed interesting discrepancies. For example, we did not find remarkable differences in anxiety between boys and girls. Although another study pointed in the same direction (Teo, 2008), most of the studies suggest gender differences (Adebowale et al., 2009; Baloğlu \& Çevik, 2008; Durndell \& Haag, 2002; Kaino, 2008; Kubiatko et al., 2011; Shasshaani, 1993).

What could explain the lack of gender differences in anxiety? One explanation could be that anxiety is inversely related to early previous use. In our sample, computers were frequently used and at early stages in life and anxiety was very low in both groups without gender differences. Socio-cultural context may also influence directly or indirectly influence anxiety in relation to ICT. Most of the studies showing high levels of anxiety were relatively old (from 2002 to 2010), and some were carried out in countries where computer use was less widespread.

The ICILS report (Fraillon et al., 2014) found, as we do, higher values in the dimensions of enjoyment for boys than girls. This finding, that boys enjoy ICT more than girls, however, is not consistent with the reviewed literature (Adebowale et al., 2009; Busch, 1995; Fančovičová \& Prokop 2008; Kaino, 2008; Ogan et al., 2005; Shashaani, 1993; Teo, 2008). We believe that a factor explaining differences in these studies and our results may actually reflect differences in ages in the samples studied and differences in the use of computers in schools and at home.

Self-confidence is marginally lower in girls, as compared with other studies (Christoph et al., 2015; Ogan et al., 2005; Volman \& Van Eck, 2001), probably due to the earlier age of the participants in our study. Clearly, the tendency is that boys tend to perceive themselves as 'experts' in ICT, even when their objective knowledge is low, while girls seem to perceive themselves as less skilful and with less knowledge, even if their objective knowledge shows no difference with boys' (Volman \& Van Eck, 2001). The low self-confidence level in girls seems to be associated with girls' tendency to undervalue themselves, boosted by informal, self-learning (Volman \& Van Eck, 2001).

\section{SELF-EFFICACY IN THE USE OF ICT}

There are hardly any differences in self-efficacy between boys and girls, contrary to what has been described in other studies pointing at less self-efficacy in girls as compared with boys (Adebowale et al., 2009; Busch, 1995; Downes \& Looker, 2011; Durndell \& Haag, 2002; Miura, 1987; Papastergiou, 2008).

However, it is important to study self-efficacy, not only as an overall index, but rather taking into account the different tasks that may determine perceptions of self-efficacy. We have reported mild gender differences in self-efficacy in different types of tasks. For example, girls report higher selfefficacy than boys in basic tasks, which is the reverse for advanced tasks, as shown as well in the ICILS report (Fraillon et al., 2014).

Both boys and girls show overall high levels of self-efficacy, which may be related to frequency of use. On the other hand, gender differences in basic and advanced tasks seem to be consistent with the types of use of computers, predominantly for advanced tasks in boys (e.g.. web creation, media management) and for basic tasks in girls (presentations, text document, emailing). Girls feel safe while doing simple and mechanical tasks, while boys tend to develop more complex and technical 
tasks. Interestingly, self-efficacy differences are consistent with the findings in self-confidence, so we believe there is a pervasive effect of our study's age range sample.

\section{CONCLUSIONS}

Our study addresses the research questions providing fundamental insights into the underlying factors explaining the large gender differences in ICT professional choices by students in Catalonia. First, students report household as their formal place of ICT learning rather than the school. Second, students' stereotyped perception on parents' abilities is heavily biased towards fathers in detriment of mothers. Finally, other gender differences were hardly detected except in certain types of computer use.

Related to the first research question (i.e., the socio-demographical context of boys' and girls' use of computers), our study showed that the formal place for students' ICT learning is the household rather than the school. Indeed, the role of schools in ICT seems to be relatively meagre and students do not take advantage of that formal learning environment despite the fact that Catalan schools have a reasonable computer-student ratio. This is a lost opportunity for the educational system to promote ICT learning and to contribute to the reduction of gender differences in their use. However, the availability of ICT equipment is not enough to ensure its proper use. It is striking that despite the increasing predominance of ICT in all sectors of society, there is hardly any guidance targeting teachers and students on how to optimise and adapt to the use of existing innovative and everchanging ICT technologies.

In this regard, the Catalan government (Generalitat of Catalonia, 2015) has recently started to take actions, such as the definition of students' and teachers' digital competences (both in primary and secondary education) and the implementation of a digital framework for schools. In order to help teachers to reinforce their ICT skills, a large teacher-training programme has been developed, focusing on methodologies, technical contents, and the pedagogical uses of ICT. Although these actions are mandatory, official educational policies, there are no proper monitoring and evaluation mechanisms to ensure that they are widely disseminated, accurately applied, and that the results meet the targets set. Our findings suggest that these actions have had hardly any impact on students' perceptions (i.e., the educational system is not the place of reference for ICT learning). Since our study participants were students just starting the secondary school, we can say that we could not show any evidence that actions taken so far in primary schools have led to a noticeable impact at the start of secondary school. Provided that the Catalan government's policy is to strengthen ICT learning in schools, this policy will have to be deployed paying more attention to implementation challenges (e.g., designing adequate pedagogical approaches accompanying equipment updates) and developing evaluation strategies that allow prompt corrective actions. The Office for Standards in Education, Children's Services and Skills (Ofsted), the evaluation organism of the UK on education, is an example of how to implement a follow up about governmental policies. Attending to ICT implementation at schools, Ofsted had published a report into information and communication technology (ICT) and its effect on achievement and standards in schools. This report draws on evidence from the inspection of ICT in primary, secondary, and special schools between 2008 and 2011 (Ofsted, 2013).

Secondly, boys' and girls' perceptions about their fathers' and mothers' ICT skills seem to be related to their personal context at home as well as to stereotyped perceptions about the gendered bias of ICT. This is actually not a problem unique to the educational sector, but rather one that affects the society as a whole; hence, actions to revert this situation have to involve not only schools but households and other sectors, as well. In Catalonia, for example, some initiatives targeting girls and also parents have been implemented, although only on an informal level and often as part of wider international initiatives. For instance, the Technovation Challenge or Girls in ICT Day consists of a series of workshops that are conducted by female professional experts in ICT. Currently, these types of actions are carried out on a voluntarily basis and are of very limited scope. Furthermore, they target an audience that is already sensitized to the need to promote the use of ICT by girls. 
Are Boys and Girls still Digitally Differentiated?

But, what has been specifically done from the Catalan educational sector? Again, not much and not in a very formal way. There are some actions, showing evidence-based results, that can be implemented: (a) training for families in the use of ICT, including technical and security issues (Stockdale \& Keane, 2016); (b) organizing sessions on vocational guidance and information on the ICT sector with the participation of professionals from the sectors, specifically women (Clayton, Beekhuyzen, \& Nielsen, 2012); and (c) sharing with families the tasks based on the use of ICT made by their children (Becta, 2008)

Finally, in relation to our two other research questions, our study found that reported gender differences in attitudes and self-efficacy are somehow smaller in our Catalan subpopulation than in other similar studies from elsewhere.

One factor that could explain this reduced gender differences may be related to the fact that our participants tended to be younger than those in other studies. Both boys and girls in our study, who have just finished primary school, show the same level of self-efficacy. This is an excellent opportunity to consider actions that maintain or even further reduce these gender differences throughout the secondary school, given that self-efficacy is closely related to the intention of continuing ICT studies in the future (Downes \& Looker, 2011). Interventions must ensure that appropriate access to equipment is granted for both boys and girls. The 1:1 projects implemented in different countries (Valiente, 2010) allow this individualised access to computers. However, these initiatives have to be coupled with an ICT integrated use plan in all areas in a transversal way, across subjects. Since the implementation of these projects has a high financial burden to education agencies, schools, and families, they are not always feasible or sustainable. In Catalan schools, the computer per student ratio facilitates an individual use of computers during most of the school timetable.

Despite the reduced gender differences in attitudes and self-efficacy, we did find significant gender difference in the frequency of computers use. In order to design engaging activities to reduce these differences, our study provides useful insights on promoting specific activities for boys and girls (i.e., boys carry out more technical activities (e.g., gaming) while girls use computers for communication). It is common practice that teachers design ICT activities without taking into account these differences. Current evidence suggests that schools should redesign ICT training in a more transversal way in which both boys and girls (a) access the whole scope of ICT applications activities, (b) engage in collaborative activities, and (c) are exposed to significant ICT contents that relate to the improvement of social needs (Ofsted, 2013). Activities must ensure that students take full advantage of their ICT skills and that they become digitals creators and critical users.

\section{REFERENCES}

Abbiss, J. (2011). Boys and machines: gendered computer identities, regulation and resistance. Gender and Education, 23(5), 601-617. http://dx.doi.org/10.1080/09540253.2010.549108

Adebowale, O., Adediwura, A., \& Bada, T. (2009). Correlates of computer attitude among secondary school students in Lagos State, Nigeria. International Journal of Computing and ICT Research, 3(2), 20-30.

Baloğlu, M., \& Çevik, V. (2008). Multivariate effects of gender, ownership, and the frequency of use on computer anxiety among high school students. Computers in Human Behavior, 24(6), 2639-2648. http://dx.doi.org/10.1016/j.chb.2008.03.003

Bandura, A. (1978). Self-efficacy: Toward a unifying theory of behavioral change. Advances in Behavior Research and Therapy, 1(4), 139-161. http://dx.doi.org/10.1016/0146-6402(78)90002-4

Bandura, A., \& Schunk, D. H. (1981). Cultivate competence, self- efficacy and intrinsic interest through proximal self-motivation. Journal of Personality and Social Psychology, 41(3), 586-598. http://dx.doi.org/10.1037/0022-3514.41.3.586

Becta (2008). Exploiting ICT to improve parental engagement, moving towards online reports. Retrieved October 2017. https://www.education.gov.uk/publications/eOrderingDownload/Exploiting ICT.pdf 
Blignaut, P. (2006). Standardised instruments for measuring computer attitude and computer anxiety are not necessarily standardised. ECIS, 886-898.

Busch, T. (1995). Gender differences in self-efficacy and attitudes toward computers. Journal of Educational Computing Research, 12(2), 147-158. http://dx.doi.org/10.2190/H7E1-XMM7-GU9B-3HWR

Carrington, B., Tymms, P., \& Merrell, C. (2008). Role models, school improvement and the "gender gap" - Do men bring out the best in boys and women the best in girls? British Educational Research Journal, 34(3), 315327. http://dx.doi.org/10.1080/01411920701532202

Castaño, C., \& Webster, J. (2011). Understanding women's presence in ICT: The life course perspective. International Journal of Gender, Science and Technology, 3(2), 364-386. Retrieved May 2017 from http://genderandset.open.ac.uk/index.php/genderandset/article/view/168

Chen, M. (1986). Gender and computers: The beneficial effects of experience on attitudes. Journal of Educational Computing Research, 2, 265-282. http://dx.doi.org/10.2190/WDRY-9K0F-VCP6-JCCD

Cheryan, S., Plaut, V.C., Handron, C., \& Hudson, L. (2013). The stereotypical computer scientist: Gendered media representations as a barrier to inclusion for women. Sex Roles, 69, 58-71.

http://dx.doi.org/10.1007/s11199-013-0296-x

Christoph, G., Goldhammer, F., Zylka, J., \& Hartig, J. (2015). Adolescents' computer performance: The role of self-concept and motivational aspects. Computers and Education, 81, 1-12. http://dx.doi.org/10.1016/j.compedu.2014.09.004

Clayton, K. L. (2007). The influence of metropolitan Brisbane middle-school ICT experiences on girls' ICT study and career choices. PhD dissertation, Griffith University, December 2007.

Clayton, K. L., Beekhuyzen, J., \& Nielsen, S. (2012), Now I know what ICT can do for me!. Information Systems Journal, 22, 375-390. http://dx.doi.org/10.1111/j.1365-2575.2012.00414.x

Clayton, K. L., von Hellens, L. A., \& Nielsen, S. H. (2009). Gender stereotypes prevail in ICT: A research review. Public Understanding of Science, 23(2), 153-158. http://dx.doi.org/10.1145/1542130.1542160

Clegg, S. (2001). Theorising the machine: Gender, education and computing. Gender and Education, 13(3), $307-$ 324. http://dx.doi.org/10.1080/09540250120063580

Colley, A., \& Comber, C. (2003). Age and gender differences in computer use and attitudes among secondary school students: what has changed? Educational Research, 45(2), 155-165. http://dx.doi.org/10.1080/0013188032000103235

Downes, T., \& Looker, D. (2011). Factors that influence students' plans to take computing and information technology subjects in senior secondary school. Computer Science Education, 21(2), 175-199. http://dx.doi.org/10.1080/08993408.2011.579811

Durndell, A., \& Haag, Z. (2002). Computer self-efficacy, computer anxiety, attitudes towards the Internet and reported experience with the Internet, by gender, in an East European sample. Computers in Human Behavior, 18(5), 521-535. http://dx.doi.org/10.1016/S0747-5632(02)00006-7

European Union Statistical Office (Eurostat). (n.d.). Survey on Digital Economy and Society. Retrieved from http://ec.europa.eu/eurostat/web/digital-economy-and-society/data/database

Everis. (2012). Factores influyentes en la elección de estudios cientificos, tecnológicos y matemáticos. Visión de los estudiantes de $3^{\circ}$ y $4^{\circ}$ de ESO y Bachillerato. Retrieved May 2017. http://s3-eu-west-1.amazonaws.com/e17r5kdatap1/everis documents downloads/estudio+vocaciones.pdf

Fančovičová, J., \& Prokop, P. (2008). Students' attitudes toward computer use in Slovakia. Eurasia Journal of Mathematics Science \& Technology Education, 4(3), 255-262.

Farkas, D., \& Murthy, M. (2005). Attitudes toward computers, the introductory course and recruiting new majors: Preliminary results. Proceeding of Programming Interest Group 17, 268-277. 
Are Boys and Girls still Digitally Differentiated?

Fraillon, J., Ainley, J., Schulz, W., Friedman, T., \& Gebhardt, E. (2014). Students' use of and engagement with ICT at home and school. Preparing for Life in a Digital Age: The IE A International Computer and Information Literacy Study International Report, 125-166. Retrieved May 2017. http://dx.doi.org/10.1007/978-3-319-14222$\underline{76}$

Francis, L. J. (1994). The relationship between computer related attitudes and gender stereotyping of computer use. Computers and Education, 22(4), 283-289. http://dx.doi.org/10.1016/0360-1315(94)90050-7

Gardner, D. G., Discenza, R., \& Dukes, R. L. (1993). The measurement of computer attitudes: an empirical comparison of available scales. Journal of Educational Computing Research, 9, 487-507.

Garland, K. J., \& Noyes, J. M. (2008). Computer attitude scales: How relevant today?. Computers in Human Behavior, 24(2), 563-575. http://dx.doi.org/10.1016/j.chb.2007.02.005

Generalitat of Catalonia (2015). Core competencies in the digital field. Retrieved June 2017 from http://ensenyament.gencat.cat/web/.content/home/departament/publicacions/colleccions/competencie s-basiques/eso/eso-ambit-digital-angles.pdf

Generalitat of Catalonia. (2017). Survey on ICT equipment and use in schools. Retrieved from http://ensenyament.gencat.cat/ca/departament/estadistiques/equipaments-usos-tic/curs-actual/

Institut d'Estadística de Catalunya (IDESCAT). (n.d.). Survey on ICT equipment and use in housebolds. Retrieved from http://www.idescat.cat/estad/ticl?lang=en

Instituto Nacional de Estadística (INE). (n.d.). Survey on Equipment and Use of Information and Communication Technologies in Households. Retrieved from http://www.ine.es/dyngs/INEbase/en/operacion.htm?c=Estadistica C\&cid=1254736176741\&menu=re sultados\&secc $=1254736194579 \& i d p=1254735576692$

Kafai, Y. B., Heeter, C., Denner, J., \& Sun, J. Y. (2008). Beyond Barbie ${ }^{\circledR}$ and Mortal Kombat: New perspectives on gender and gaming. Games and Culture,1(1), 83-88.

Kaino, L. M. (2008). Technology in learning: Narrowing the gender gap? Eurasia Journal of Mathematics, Science and Technology Education, 4(3), 263-268.

Kubiatko, M. (2013). The comparison of different age groups on the attitudes toward and the use of ICT. Educational Sciences: Theory and Practice, 13(2), 1263-1272. Retrieved May 2017 from http:// files.eric.ed.gov/fulltext/EJ1017271.pdf

Kubiatko, M., Haláková, Z., Nagyová, S., \& Nagy, T. (2011). Slovak high school students' attitudes toward computers. Interactive Learning Environments. http://dx.doi.org/10.1080/10494821003612232

Loyd, B. H., \& Gressard, C. (1984). Reliability and factorial validity of computer attitude scales. Educational and Psychological Measurement, 44, 501-505. http://dx.doi.org/10.1177/0013164484442033

Master, A., Cheryan, S., \& Meltzoff, A. N. (2016). Computing whether she belongs: Stereotypes undermine girls' interest and sense of belonging in computer science. Journal of Educational Psychology, 108, 424-437. http://dx.doi.org/10.1037/edu0000061

Miura, I. T. (1987). The relationship of self-efficacy expectations to computer interest and course enrollment in college. Sex-roles, 16, 303-311. http://dx.doi.org/10.1007/BF00289956

Nash, J., \& Moroz, P. (1997). An examination of the factor structures of the computer attitude scale. Journal of Educational Computing Research, 17(4), 341-356.

OECD. (2005). PISA 2003 Technical Report, 425. Retrieved May 2017. http://www.oecd.org/edu/school/programmeforinternationalstudentassessmentpisa/35188570.pdf

OECD. (2012). PISA 2009 Technical Report, PISA, OECD Publishing. Retrieved May 2017. http://dx.doi.org/10.1787/9789264167872-en

OECD. (2015a). The ABC of Gender Equality in Education: Aptitude, Behaviour, Confidence, PISA, OECD Publishing. Retrieved May 2017. http://dx.doi.org/10.1787/9789264229945-en

OECD. (2015b). Students, Computers and Learning: Making the Connection, OECD Publishing, Paris. Retrieved May 2017. http://dx.doi.org/10.1787/9789264239555-en 
Ofsted. (2013). ICT in schools 2008-11. An evaluation of information and communication technology education in schools in England 2008-11. Ofsted. Retrieved October 2017 from https://www.gov.uk/government/uploads/system/uploads/attachment data/file/181223/110134.pdf

Ogan, C., Herring, S. C., \& Robinson, J. C. (2005). International Communications Association Conference. The More Things Change, the More They Stay the Same: Gender Differences in Attitudes and Experiences Related to Computing Among Students in Computer Science and Applied Information Technology Programs.

Papastergiou, M. (2008). Are computer science and information technology still masculine fields? High school students' perceptions and career choices. Computers and Education, 51(2), 594-608. http://dx.doi.org/10.1016/i.compedu.2007.06.009

Pechtelidis, Y., Kosma, Y., \& Chronaki, A. (2015). Between a rock and a hard place: Women and computer technology. Gender and Education, 27(2), 164-182. http://dx.doi.org/10.1080/09540253.2015.1008421

Powell, A. L. (2013). Computer anxiety: Comparison of research from the 1990s and 2000s. Computers in Human Behavior, 29(6), 2337-2381. http://dx.doi.org/10.1016/i.chb.2013.05.012

Sáinz, M., \& López-Sáez, M. (2010). Gender differences in computer attitudes and the choice of technologyrelated occupations in a sample of secondary students in Spain. Computers and Education, 54(2), 578-587. http://dx.doi.org/10.1016/i.compedu.2009.09.007

Sáinz, M., Pálmen, R. \& García-Cuesta, S. (2012). Parental and Secondary School Teachers' Perceptions of ICT Professionals, Gender Differences and their Role in the Choice of Studies. Sex Roles, 66(3-4), 235-249. http://dx.doi.org/10.1007/s11199-011-0055-9

Sáinz, M., Meneses, J., Fàbregues, S., \& López, B. (2016). Adolescents' gendered portrayals of information and communication technologies occupations. International Journal of Gender, Science and Technology 8(2), 81-201.

Selwyn, N. (1997). Students' attitudes toward computers: Validation of a computer attitude scale for 16-19 education. Computers and Education, 28(1), 35-41. http://dx.doi.org/10.1016/S0360-1315(96)00035-8

Shashaani, L. (1993). Gender-based differences in attitudes. Computers and Education, 20(2), 169-181.

Sjøberg, S., \& Schreiner, C. (2010). The ROSE project: An overview and key findings. Oslo: University of Oslo, 131. Retrieved May 2017 from http://www.uv.uio.no/ils/english/research/projects/rose/publications/therose-project.pdf

Stockdale, R., \& Keane. T. (2016). Influencing the influencers: The role of mothers in IT career choices. Journal of Information Technology Education: Innovations in Practice, 15, 181-194. https://doi.org/10.28945/3624

Teo, T. (2008). Assessing the computer attitudes of students: An Asian perspective. Computers in Human Behavior, 24(4), 1634-1642. http://dx.doi.org/10.1016/j.chb.2007.06.004

Thomas, T. \& Allen, A. (2006). Gender differences in students' perceptions of information technology as a career. Journal of Information Technology Education: Research, 5, 165-168. https://doi.org/10.28945/241

Valiente, O. (2010). 1-1 in education current practice, International comparative research evidence and policy implications. OECD Education Working Papers, 44. OECD Publishing. http://dx.doi.org/10.1787/5kmjzwfl9vr2-en

Varank, I. (2007). Effectiveness of quantitative skills, qualitative skills, and gender in determining computer skills and attitudes: A causal analysis. The Clearing House: A Journal of Educational Strategies, Issues and Ideas, $81(2), 71-80$

Vekiri, I. (2010). Boys' and girls' ICT beliefs: Do teachers matter?. Computers and Education, 55(1), 16-23. https://doi.org/10.1016/j.compedu.2009.11.013

Volman, M., \& van Eck, E. (2001). Gender equity and information technology in education: The second decade. Review of Educational Research, 71(4), 613-634. http://dx.doi.org/10.3102/00346543071004613

Volman, M., van Eck, E., Heemskerk, I., \& Kuiper, E. (2005). New technologies, new differences. Gender and ethnic differences in pupils' use of ICT in primary and secondary education. Computers and Education, 45(1), 35-55. http://dx.doi.org/10.1016/j.compedu.2004.03.001 
Are Boys and Girls still Digitally Differentiated?

Von Hellens, L., Clayton, K., Beekhuyzen, J., \& Nielsen, S. (2009). Perceptions of ICT careers in German Schools: An exploratory study. Journal of Information Technology Education, 8. 211-228.

https://doi.org/10.28945/168

\section{APPENDIX A: QUESTIONNAIRE}

SOCIO-DEMOGRAPHIC CONTEXT

\begin{tabular}{|ll|}
\hline \multicolumn{1}{|c|}{ QUESTIONS } & \multicolumn{1}{c|}{ ANSWERS } \\
\hline Gender & Boy / Girl \\
\hline Age & $11 / 12 / 13 / 14 / 15$ \\
\hline Name of school & Open answer \\
\hline Dou you have a computer at home? & Yes, mine/Yes, shared/No \\
\hline When do you start using a computer? & Before 6/Between 6 and 8/Between 9 and 11/After 12 \\
\hline $\begin{array}{ll}\text { Where did you use a computer for the first time? } \\
\text { Which level of ICT skills do you think having } \\
\text { your father? }\end{array}$ & $\begin{array}{l}\text { At home/At school/At a relative's home/At a friend's } \\
\text { home }\end{array}$ \\
\hline $\begin{array}{l}\text { Which level of ICT skills do you think having } \\
\text { your mother? }\end{array}$ & Very high/High/Low/Very low/NA \\
\hline $\begin{array}{l}\text { Who do you ask for help when you have a com- } \\
\text { puter problem? }\end{array}$ & Father/Mother/Brother-Sister/Friends \\
\hline $\begin{array}{l}\text { Where do you think you learn to use computers? } \\
\text { Ond }\end{array}$ & $\begin{array}{l}\text { On my own at home/At school/At home with some } \\
\text { help/With friends }\end{array}$ \\
\hline
\end{tabular}

FREQUENCY OF USE: Indicate how often you perform the following tasks with your computer

(Possible answers: Almost never/Once or twice a month/Once or twice a week/Almost everyday)

\begin{tabular}{|l|}
\hline QUESTIONS \\
\hline Gaming \\
\hline Forums/Social networks \\
\hline Schools homework \\
\hline Email \\
\hline Chats \\
\hline Surfing the Internet \\
\hline Downloading music, games, films \\
\hline Maintaining a personal web or blog \\
\hline
\end{tabular}


ATTITUDES: Indicate the extent to which you agree or disagree with the ideas expressed

(Possible answers: Strongly disagree/Disagree/Agree/Strongly agree)

\begin{tabular}{|c|c|}
\hline QUESTIONS & RELATED VARIABLE \\
\hline Computers do not scare me at all & Anxiety \\
\hline I would like working with computers & Enjoyment \\
\hline Working with a computer would make me very nervous $\left(^{*}\right)$ & Anxiety \\
\hline I do not feel threatened when others talk about computers & Anxiety \\
\hline It wouldn't bother me at all to take computer courses & Anxiety \\
\hline I'm no good with computers $\left(^{*}\right)$ & Self-confidence \\
\hline The challenge of solving problems with computers does not appeal to me $\left(^{*}\right)$ & Enjoyment \\
\hline Computers make me feel uncomfortable $\left(^{*}\right)$ & Anxiety \\
\hline Generally, I would feel OK about trying a new problem on the computer & Self-confidence \\
\hline I would feel at ease in a computer class & Anxiety \\
\hline I think working with computers would be enjoyable and stimulating & Enjoyment \\
\hline I don't think I would do advanced computer work $\left(^{*}\right)$ & Self-confidence \\
\hline Figuring out computer problems does not appeal to me $\left(^{*}\right)$ & Enjoyment \\
\hline I get a sinking feeling when I think of trying to use a computer $\left(^{*}\right)$ & Anxiety \\
\hline I am sure I could do work with computers & Self-confidence \\
\hline I would feel comfortable working with a computer & Anxiety \\
\hline $\begin{array}{l}\text { When there is a problem with a computer run that I can't immediately solve, I } \\
\text { would stick with it until I have the answer }\end{array}$ & Enjoyment \\
\hline I'm not the type to do well with computers $\left(^{*}\right)$ & Self-confidence \\
\hline $\begin{array}{l}\text { I don't understand how some people can spend so much time working with } \\
\text { computers and seem to enjoy it }(*)\end{array}$ & Enjoyment \\
\hline I am sure I could learn a computer language & Self-confidence \\
\hline Once I start to work with the computer, I would find it hard to stop & Enjoyment \\
\hline I think using a computer would be very hard for me $\left(^{*}\right)$ & Self-confidence \\
\hline I will do as little work with computers as possible $\left(^{*}\right)$ & Enjoyment \\
\hline Computers make me feel uneasy and confused $\left(^{*}\right)$ & Anxiety \\
\hline $\begin{array}{l}\text { If a problem is left unsolved in a computer class, I would continue to think } \\
\text { about it afterward }\end{array}$ & Enjoyment \\
\hline I could get good grades in computer courses & Self-confidence \\
\hline I do not enjoy talking with others about computers $(*)$ & Enjoyment \\
\hline I do not think I could handle a computer course $\left(^{*}\right)$ & Self-confidence \\
\hline I have a lot of self-confidence when it comes to working with computers & Self-confidence \\
\hline I feel aggressive and hostile toward computers $(*)$ & Anxiety \\
\hline
\end{tabular}

Note: $\left(^{*}\right)$ Items for which score is reversed 
Are Boys and Girls still Digitally Differentiated?

SELF-EFFICACY: Indicate what you think is your level with respect to the following tasks

(Possible answers: I don't know what it means/I can't do it/I can do it with help/I can do it on my own)

\begin{tabular}{|l|}
\hline QUESTIONS \\
\hline Edit digital images \\
\hline Create a database \\
\hline Use a spread sheet \\
\hline Create a presentation \\
\hline Create a multimedia presentation with images, sounds and videos \\
\hline Create a text document \\
\hline Work in collaborative documents \\
\hline Create a web page \\
\hline Create a blog \\
\hline Read and answer email \\
\hline
\end{tabular}

\section{APPENDIX B: TABLE OF RESULTS}

Results of Frequency of use, Attitudes and Self-efficacy

\begin{tabular}{|lcccc|}
\hline & \multicolumn{2}{c}{ BOYS } & \multicolumn{2}{c|}{ GIRLS } \\
ATTITUDES & SE & Mean & SE \\
Anxiety & 3.38 & 0.022 & 3.35 & 0.017 \\
Enjoyment & 3.03 & 0.021 & 2.89 & 0.023 \\
Self-confidence & 3.23 & 0.022 & 3.09 & 0.026 \\
Attitude Index & 3.21 & 0.020 & 3.11 & 0.020 \\
FREQUENCY OF USE & & & & \\
Leisure frequency & 2.59 & 0.029 & 2.37 & 0.033 \\
Game frequency & 2.54 & 0.048 & 1.91 & 0.045 \\
Communication frequency & 2.94 & 0.042 & 3.09 & 0.034 \\
Homework frequency & 3.17 & 0.089 & 3.28 & 0.081 \\
Frequency Index & 2.79 & 0.025 & 2.75 & 0.022 \\
SELF-EFFICACY & & & & \\
Basic level & 3.66 & 0.021 & 3.70 & 0.016 \\
Advanced level & 3.23 & 0.021 & 3.21 & 0.023 \\
Self-efficacy index & 3.44 & 0.017 & 3.45 & 0.016 \\
\hline
\end{tabular}

\section{BIOGRAPHIES}

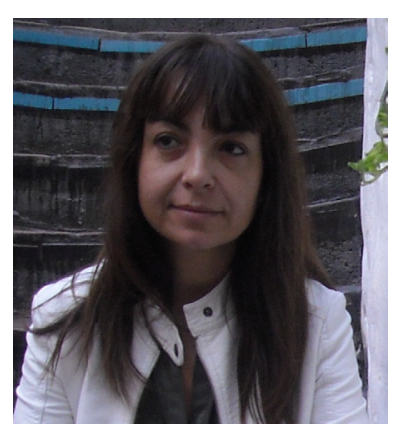

Roser Cussó-Calabuig is an Associate Professor of Master's Degree in Secondary and Upper Secondary Education at the Universitat Politècnica de Catalunya (Barcelona'Tech). She holds a Master's Degree in Technological Education and she is carrying on her $\mathrm{PhD}$ investigation focused on Gender and Technology (Universitat de Lleida, UdL). She has worked as a Technology and ICT teacher at Secondary Education and currently she is working as a technological advisor at the Department of Education of the Catalan Government. 

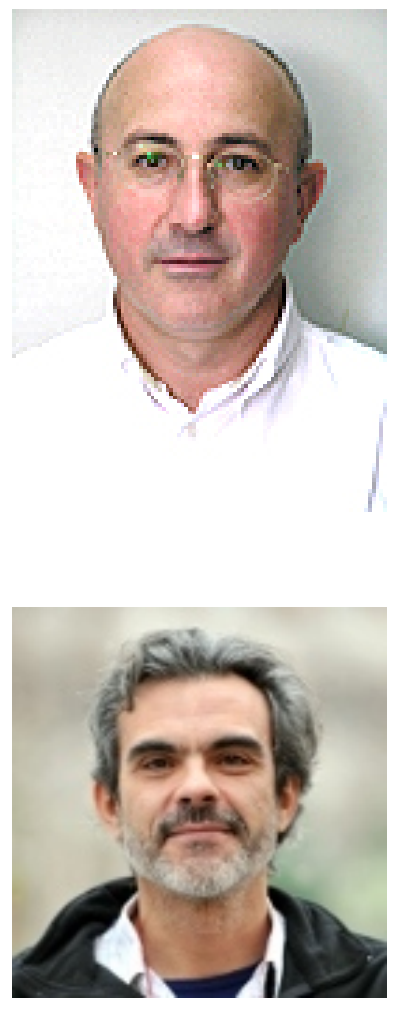

F. Xavier Carrera Farran is an Associate Professor of Educational Technology in the Department of Pedagogy and Psychology at the University of Lleida (UdL), Spain. PhD in Psychopedagogy. Extraordinary Doctorate Award. Member of COMPETECS (Competences, Education, Technology and Society) research group. Coordinator at the University of Lleida in the Interuniversity Doctorate Program in Educational Technology. His research interests are Technology in Education, the application of active methodologies in education and the training based on competences.

Xavier Bosch-Capblanch is a Medical Doctor, with an official medical speciality in Public Health (Spain), MSc in Tropical Medicine and Hygiene (Spain) and $\mathrm{PhD}$ (evidence on unvaccinated children in LMIC and policy implication, University of Amsterdam). He is Group Leader (Data-

Evidence-Evaluation-Policy') at the Swiss Tropical and Public Health Institute (Basel, Switzerland). He is also Honorary Lecturer at the Liverpool School of Tropical Medicine. He has been involved in several initiatives to bridge the gap between research evidence and management and policy making. 